\title{
Opportunities and Constraints within the Agribusiness Industry in the Emerging Market of Ghana
}

\author{
Richard Asante $^{1^{*}}$, Rheeta Marjery ${ }^{2}$, Frank Boateng ${ }^{3}$ \\ ${ }^{1}$ Business Development Manager, AECI process and water, West Africa \\ ${ }^{2}$ Principal, Sree Pashmi Institute of Management, India \\ ${ }^{3} \mathrm{Ag}$. Head, management studies department, UMAT, Ghana
}

\begin{abstract}
The purpose of the study is to conduct an empirical investigation into the important role of technology in a value-driven business process design for an emerging market. Emerging markets are characterized by low GDP because of low economic activities. However, it is full of business opportunities within its environments for prospective businesses or existing small business which wants to scale up or globalize. Moreover, many business constraints exist some are poor technological infrastructure, institutional voids, bribery and corruption, bureaucracy, and poorly trained human capital. There was a critical examination of extant studies by several scholars and researchers related to the objective of the study. The main focus of the review is to establish strong conceptual, theoretical, and empirical support for this study. These included segments that dealt with the conceptual framework review of competitive advantage and theoretical reviews of the Network Theory. Structured as the third segment is the empirical review. This entails an in-depth review of extant studies related to the three-pronged objectives, with the aim of either rejecting or accepting the underlying framework in such studies. Thematic analysis was employed for analysing the primary data collected via focus group discussion plus in-depth interviews. An in-depth examination of the responses of participants revealed that though the majority (19) of the participants agreed that emerging market has several potential and benefits, yet they indicated the existence of certain constraints mitigating increased investment in agribusiness in Ghana, as demonstrated in the excerpt.
\end{abstract}

Keywords: Constrains, Emerging market, Opportunities.

\section{Introduction}

Several studies provide ample information regarding the several opportunities associated with an emerging market and strongly believe that such opportunities are minimally tapped. For example, the interest in emerging markets offers comes is in part because they offer phenomenon fast growth and entail the potential for further growth. Growth rates have generally slowed for instance, after Goldman Sachs started "dreaming with BRICs," referring to the emerging economies of Brazil, Russia, India, and China [1]. But as developed economies offer small or no market growth during these austerity moments, emerging markets look more promising for businesses to sustain and grow their revenue and profitability. Moreover, a larger percentage of emerging economies is marked with a faster rate of economic growth in GDP than in developed countries. It was discovered that cutting-edge technology could be very useful within an emerging economy due to the developing nature of the economy and less saturation of technological innovation in comparison to a developed economy [2]. A study also indicated

Received: 25.11.2021

Accepted: 17.12.2021

Published on: 28.02.2022

*Corresponding Author: rasanten348@gmail.com 
that emerging markets are not as stringent and efficient as well as with less sophistication in comparison to markets in developed economies where bureaucracies and high standard of security and tax deduction together with security regulation could drain out initial capital for a startup [3].

\section{Conceptual Framework}

\section{Concept of Competitive Advantage}

The concept of competitive advantage has been described by [4] as terminology that "might garner the prize for the most overworked and least understood catch-phrase" (p. 32). [4] further stated that extension of the terminology into "sustainable competitive advantage", is at present, an elaboration of ambiguity" (p. 48). Deepening the controversy surrounding competitive advantage, [5] asserted that over time business strategy has gradually substituted competitive advantage, and scholars are puzzled regarding what constitutes a competitive advantage.

An important component of the successful establishment of a value chain business in an emerging market is a competitive advantage. There is fierce competition among businesses due to the revolutionary trend of technology and globalization; hence firms must make a concerted effort at building and maintaining requisite skills and competencies and exhibit dynamism in adapting to the new environment [6], as well as meeting the fleeting demands of customers, values, and processes [7]. It is observed in [8] that challenges associated with competition and customer needs and a tumultuous business environment can be successfully met with the application of the conceptual framework of competitive advantage. However, asserted that due to a plethora of confusing information, a strategic manager disentangles the knotty gaps, the dichotomy of opinion, and ambiguity surrounding competitive edge to orchestrate his exploiting all avenues to gain a competitive edge in an emerging market [8]. This notion impels the review of the concept of a competitive edge.

Competitive edge has been variously defined, described, and explained following the groundbreaking coinage of the expression by [9]. For example, [10] sees the competitive advantage as a set of executable actions or qualities by a business organization to outdo its competitors. This can be described from the perspective of when the business operation of an organization yields more profit than those of its competitors or in a situation where the organization tower over competitors in several other significant aspects of business operations in a given market. In his notable work, [11] provides a succinct description of what influences competitive advantage. The description provides insight and captures the complexity regarding competitive advantage as well as the overall objective of the study. [11] conceives competitive advantage and the resultant improved organizational performance as representative of the adaptive ability of an organization to its environment, underscoring the point that a business organization that succeeds in adapting to the environment it operates should be capable of matching its strength with the numerous opportunities within its environment including emerging market. Hence, [11] categorized factors influencing adaptation into four-pronged issues:

1. "Whether the firm's strategy is congruent with its industry structure and competitive context".

2. "Whether its organizational structure fits its environment and strategy".

3. "Whether its management systems fit its strategy".

4. "Whether its management style is tailored to the strategic context including the development of right competencies".

There are other schools of thought regarding how competitive advantage should be analyzed. Two have gained prominence in recent times, and these are: 1) Resource-Based View and 2) Position-based view. Promoting a resource- 
based view, some scholars such as [13-15] felt competitive advantage can be analyzed using a resource-based view. From their standpoint, they believe that when resources in a given market are scarce, appropriable, specialized, rare, valuable, cannot be duplicated strategically, and difficult to imitate, it will gain a competitive advantage. Lending credence to the resource-based view of competitive advantage, by competitive advantage, [16] also refers to sustainable competitive advantage, which is a situation where a firm is capable of creating true value that is difficult for competitors to copy. A firm in this situation is able to earn economic rents. In effect, if a single unit of the product costs five cedis, the cost of production should be lower than five and perhaps four cedis for profitability purposes. The perceived value of the product among customers should be higher than what they pay for the product. In recent times, scholars and managers have expanded the horizon and conducted studies to critically investigate strategic mechanisms related to the attainment of competitive advantage with responsible CSR to ensure sustainability.

A Study [17] introduced the concept of a resource-based view of competitive advantage to address the shortcomings of environmental models to link up heterogeneous resources, their mobility, and its strategic or competitive advantage. This is represented in figure 3 below.

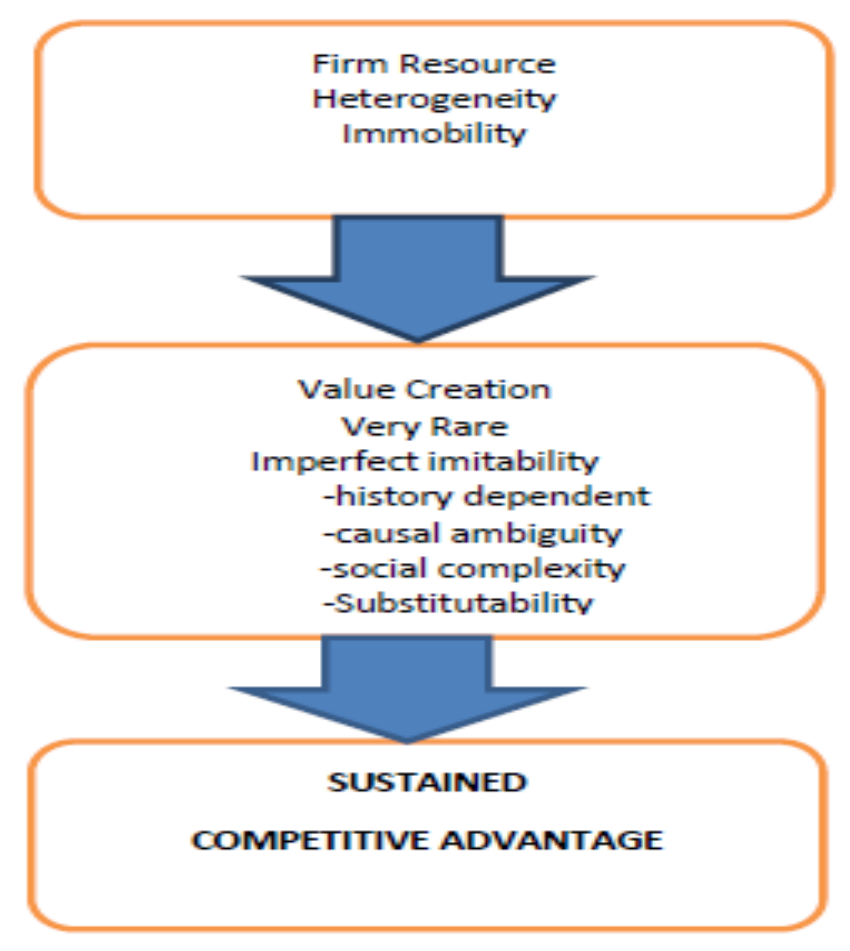

Figure 1. Resource-Based View of Competitive Advantage

Source: Adapted from Barney (1991)

On the other hand, the position view of analyzing competitive advantage places emphasis on the exploitation of the unique position of the business, the environment, and raw materials with a view to minimizing cost, maximizing profit, and continually sustain competitive advantage and business ideals.

\section{Theoretical Framework}

\section{Network Theory}

As an offshoot of U-Model, Network Theory considers a firm's entry into emerging markets from the perspective of interdependent the proponent of network theory argues that due to the complex interactions within an emerging 
market, it is difficult for firms to follow the sequential or incremental steps espoused by the U-model theory. Within a Business Network Context In business-to-business settings, dyadic relationships between firms are of paramount interest [18]. Instead, prospective firms rely on resources of accruing from partners within the sector and market. [19] refer to this network as an ecosystem. The diagram in Figure 1 vividly portrays the opportunities and constraints that a prospective firm may experience when entering into an emerging market comprising several upstream and downstream partners.

External complement challenges

\begin{tabular}{|c|c|c|}
\hline & Low & High \\
\hline 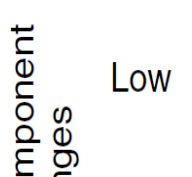 & $\begin{array}{l}\text { Internal innovation } \\
\text { challenges }\end{array}$ & $\begin{array}{l}\text { Internal challenges + } \\
\text { external constraint } \\
\text { on consumption }\end{array}$ \\
\hline 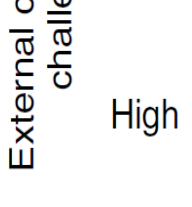 & $\begin{array}{l}\text { Internal challenges + } \\
\text { external constraint } \\
\text { on production }\end{array}$ & $\begin{array}{c}\text { Internal challenges + } \\
\text { external constraints } \\
\text { on production and } \\
\text { consumption }\end{array}$ \\
\hline
\end{tabular}

Figure 2. Impact of Ecosystem Challenges on a Prospective Investor

Source: Adner and Kapoor (2009)

A closer study of figure 1 shows that most of the literature on network theory often focuses on the first quadrant by the left with low external challenges. This implies that as soon as the firm overcomes her internal challenges, it can successfully enter into the merging market. However, the remaining three quadrants show reveals high external component challenges as well as internal challenges to be overcome before the firm can enter into the emerging market.

\section{The Implication for the Proposed Study}

The theory underpins the focus of the study because it underscores the gap in the literature concerning the constraints a prospective firm could encounter before successful integration into the market. Initially, it was conceived that as soon as a firm overcomes the internal challenges of integrating technology as a source of value creation, it would have attained a competitive advantage.
However, in the works of many researchers, including [19] studies, external challenges arising from interdependent partners concerning the use of appropriate technology could seriously impact any success a firm could attain even if it has overcome internal challenges within its establishment.

For example, a plastic corporation only needs to device appropriate technology to produce its plastic. Suppliers, customers, and others need not worry about complementing the technology employed in the production of plastics. However, a firm such as a hotel would need its upstream (suppliers) and downstream (customers) partners to cooperate with the technologies adopted for operations otherwise, the firm may not be viable.

However, the nature of challenges to be confronted by individual firms entering into emerging markets differs. A firm to use cuttingedge technology for value creation and maintenance of a competitive edge must carefully consider the best form of technology 
during process design. Hence, there is a need to fill the lacuna in understanding regarding a firm interested in agribusiness in an emerging market economy.

\section{Literature Review}

Emerging markets are very competitive and are constantly growing with new trends and technology alongside several constraints. This underscores the fact that an agribusiness investor should calculate the cost by making a novel decision on ensuring competitive advantage, increased productivity, and continuity. All of which can be done by the adoption of appropriate technology [20]. Every strategy should be directed towards overcoming entry or emerging constraints and leveraging on existing advantages.

This paper examines an issue which in within the jurisdiction of Ghana, an emerging economy in sub-Sahara Africa, from independence to 2020[20]. A historical review of post-independence government policies shows three distinct phases of technological transformation. These include.

1. Adopting "science for development" strategy and convergence of science and industrial policy between 1957 to 1966 .

2. The divergence of science policy and industrial policy between 1967 to the 1990s after the overthrow of Dr Nkrumah's government.

3. The emergence of the "new dawn" from the 2000s which ushered in a brand-new policy framework for national science and technology policy formulated towards economic development.[20].

However, the review argues that there are several constraints leveled against the instrumentality of technology in the process of designing value-driven business within an emerging market such as Ghana in sub-Saharan Africa [21]. Despite these constraints, it remains a potent variable and an inextricable element for successful business ventures in the emerging market. Conceptual and theoretical frameworks were synthesized to determine whether several theories underpinning the influence of technological innovation need modification given the ever-changing terrain of technological breakthroughs.

In fulfilling the main objective of the study, the researcher seeks to retrieve firsthand information regarding the socio-economic and day-to-day realities in African society. Hence, the review contended that most of the studies on the facilitation of value-driven business within the environment of the emerging market are secondary data. It has limited studies employing primary data or empirical investigation as an approach to research.

The findings of several studies [22] revealed that there are certain limiting factors associated with emerging markets. These include digital infrastructural constraints, shifting sand of tax law on digital technology, poor digital security, and localization. This study argues that rigorous interrogation of extant studies along with empirical findings will help in distilling relevant information. This information is useful in developing the innovative approach which, if used by investors, can override these hurdles and create a value chain and thriving enterprise in Agribusiness.

\section{Empirical Review}

This section of the study critically examined extant literature about the objectives of the study. Studies were examined chronologically to isolate gaps in the literature and elicit strong empirical support for the focus of the present study. The review in this section examined relevant studies in connection with several market opportunities within emerging markets ready for exploitation by an investor or business organization alongside constraints that may limit such exploitation.

The empirical review also touched on the inestimable benefit of technology-savvy businesses over the traditional businesses in terms of a competitive edge as well as profit margin. Another aspect of technology-savvy 
businesses was also examined, especially about Corporate Social Responsibility, which is considered an important factor in competitive advantage within an emerging market [23].

\section{Market Opportunities and Constraints in Emerging Market}

Several studies provide ample information regarding the several opportunities associated with an emerging market and strongly believe that such opportunities are minimally tapped. For example, due to the availability of financial infrastructures such as stock exchange platforms, banks, and unified currency, organizational leaders usually exploit these avenues to tap limitless opportunity for new business organization because it often yields high returns due to reduced tax deductions in comparison to developed economies. Moreover, a larger percentage of emerging economies is marked with a faster rate of economic growth in GDP than in developed countries. However, financial globalisation has been associated with divergent current account patterns in emerging markets. [24] Found out that better developed and more integrated financial markets increase emerging markets' ability to borrow abroad.

[24] discovered that cutting-edge technology could be very useful within an emerging economy due to the developing nature of the economy and less saturation of technological innovation in comparison to a developed economy. [3] also indicated that emerging markets are not as stringent and efficient as well as with less sophistication in comparison to markets in developed economies where bureaucracies and high standard of security and tax deduction together with security regulation could drain out initial capital for a startup.

Over the last two decades, emerging market economies (EMEs) have become a dominant presence in the world economy. They now account for a substantial share of world output and, with their rapid growth rates, have become a major driver of global growth during the past decade. Trade and financial linkages between advanced economies and EMEs have also become much stronger, speeding up the process of global integration [25].

Developing nations have poor distribution systems. In large cities, distribution is often through small, hole-in-the-wall shops such as the paanwalla shops in India, the tiendas de la esquinas in Mexico, and sari-sari stores in the Philippines [22].

A market of 600 million is locked in India's villages, 42 percent of which have populations of less than 500, with weak connections to the outside world. The lack of media, roadways, and electricity creates seemingly impenetrable barriers. Some villages don't have retail outlets at all, and some distribution opportunities, such as market days or carnivals, are temporary in nature [22].

New incumbents must adopt innovative networking, diversification, employ technological innovation, internationalize, and develop rare requisite skill scarce in an emerging market.

In an extensive study, [26] explored several opportunities and constraints associated with the emerging market. The study was conducted using a qualitative research paradigm and multiple case research design. An in-depth interview was used as an instrument for the study. The interview was conducted with only three business leaders and members of the management staff in three organizations in Nigeria. Such constraints involve weak institutions, unbalanced emphasis on informal institutions over formal ones, pressure arising from local government intervention in business activities, institutional transition, and changes.

A [26] study revealed that the adoption of a multiple case study research design was very appropriate for the study since the philosophy of the study was interpretative and deductive. Though it mentioned the constraints associated with an emerging market, it also discussed certain business opportunities associated with the emerging market. His study revealed that an investor bent on tapping into an emerging 
market can overcome the constraint endemic in the emerging market by having a resourcebased view of competitive edge. [26] argued that instead of modifying the already existing business model, Multinational corporations or new investors should critically examine the local market, design, and produce local products commensurate to the emerging market environment with a certain group of consumers or customers in mind.

The reviewed studies revealed that while the emerging market is riddled with a lot of weaknesses that can complicate business operation, it is can be transformed into an enabling environment for a thriving business dependent on the innate resourcefulness of prospective investors. It is also worthwhile for a prospective business that emerging market is loaded with several opportunities ranging from cost minimization (cheap labor and accessibility to raw materials at a reduced price, access to a larger market in comparison to domestic markets, to diversification, increased productivity (large scale) and profit interested in the emerging market must have the tenacity and decisiveness in making proactive move regarding product design and customer relations so that each product is representative of the commitment of the new incumbent.

\section{Methodology}

An inestimable aspect of research project is the systematic approach to the collection of relevant information, with a view to filling the lacuna in literature as well as adequately addressing research problems [27] In a bid to garner rich data culminating in well-validated and reliable findings, the method adopted, should be unbiased and rigorous [28].

A critical examination of the theories undergirding the present study, comprising Network Theory, necessitates the adoption of interpretivism as the research philosophy. The theoretical perspective of interpretivism revolves around making sense of the subjective intention and varied meanings of subjects within a context or universe of a study, without the imposition of a priori analytic groupings $[29,30]$.

Interpretivism entails concerted effort by the researcher at understanding the world from the viewpoint and first-hand information retrieved from the study's participants.

Findings of several studies [29, 31, 32], reveals that there are three-pronged approaches to the research project, namely: 1) quantitative paradigm, 2) qualitative paradigm, and 3) mixed-methods combining qualitative and quantitative research paradigms. After a careful examination of the three forms of research paradigms, the qualitative research paradigm is adopted for this study in view of the research philosophy guiding the study. [33] Indicated that qualitative paradigm is useful in conducting an in-depth investigation concerning the subject matter of a study and enhance researchers' ability to employ case studies or multiple case studies with a view to furnishing a narrative or descriptive account of practice or design.

Qualitative research design is very suitable for the study because it facilitates efforts at gaining a deeper understanding of the relevant facets for the collection of well-validated information based on first-hand experience of participants' void of manipulation by the researcher. [34] indicated that like quantitative research design, qualitative studies can also be generalized into bigger population.

Relevant data was elicited from 22 participants. In-depth interview was conducted with 10 participants comprising both management and non-management staff. For the purpose of moderating Focus Group Discussion, 12 participants were divided into three groups comprising four participants with a view to distilling relevant information related to the focus of the study.

Process managers and other professionals such as those in the $R \& D$ and Marketing Department were interviewed. I consulted relevant sources, including peer-reviewed 
sources with the aim of bridging the gaps identified at the outset of the study as well as retrieve valuable information to aid resolution of research problems. Due to the successes, they have achieved in their respective businesses, and they possess a wealth of experience on transcending limiting factors such as unpredictable market forces, weak institutions, and difficulty associated with the selection of the most appropriate technology. Participants comprised 12 men and 10 women.

The majority (14) of the participants have over 8 years of working experience, 4 had over 12 years of working experience, while the remaining 4 had less than 8 years of working experience. This clearly demonstrated that these group of participants can provide rich data as far as the focus of this study is concerned.

\section{Research Instruments/Measurements}

The proposed study will employ two major instruments for data collection. Structure interview guide and focus group discussions will be relevant in collecting pertinent information from participants and respective cases. Suggesting appropriate means of employing a structured interview guide, [35] indicated that an interview guide should be designed so as to elicit the best possible information from the participants to the end of enriching the findings of the study. This means much attention will be given to the content of the interview guide.

The guide will be structured so as to touch on relevant issues that would fast track resolution of the research question. The guide will elicit important information regarding the potentials and constraints alongside the nature of competition associated with emerging markets. It will also entail open-ended questions probing how firms, especially locally owned ones, can exploit the numerous opportunities in an emerging market using appropriate technology. The guide will also touch on how these firms' overcome constraints that could have mitigated entry into emerging markets or continuity of value-creation and competitive edge.

[36] posited that the Focus Group interview (FGI) is a highly result-oriented and credible instrument for data collection in a qualitative research approach. [36] defined Focus Group Interview as a technique where participants are drawn from various backgrounds within the sphere of the phenomenon under study to discuss and relieve complex personal experiences, perceptions, beliefs, attitudes, and perceptions via a moderated or coordinated interaction. [37] succinctly stated that it creates an avenue where the researcher co-creates meaning with participants on the given subject, phenomenon, or topic under consideration. Conducting the focus-group discussion was extremely cost-effective and was advantageous, as it allowed several people to participate at once in a short amount of time. Focus-group discussions allow the researcher to observe the interaction and non-verbal cues within the group. The participants are also able to support each other when points are discussed, which has the potential to evoke deeper conversation and views on the subject matter [37].

As a result, stakeholders in the agribusiness would be selected for the study and interviewed as well as participate in focus group discussion alongside other staff within the firm. This will ensure the co-creation of meanings regarding the focus of the study.

\section{Techniques for Data analysis}

Thematic analysis will be employed for analyzing primary data collected via focus group discussion and in-depth interviews. According to [38], thematic analysis involves immersion in textual data with the sole aim of deciphering and identifying emerging trends, patterns, and themes for analysis.

In order to gather credible and reliable data, all interview and focus group discussions were recorded with a digital recorder based on the consent of participants. Recorded interviews and discussions were played afterward and 
manually transcribed for identification of trends, patterns and themes relevant to the resolution of research problems.

The themes generated will be used as a major reference point for the analysis. In certain cases, verbatim quotations from transcribed data will be reproduced to enable readers to feel the pulse of the study and deepen knowledge on strategic management associated with appropriate technology, value-creation, and emerging market [2, 39, 40].

There are various approaches to conducting thematic analysis, but the most common form followed is a six-step process:

1. Familiarization.

2. Coding.

3. Generating themes.

4. Reviewing themes.

5. Defining and naming themes.

6. Writing up.

\section{Results}

The primary focus of this chapter is to unravel relevant insight, trends, patterns, and themes from the elicited data for the study. In effect, this section deals with findings or outcomes of the study within the context of the transcribed data retrieved from the field. The overarching objective of the study is to conduct an empirical investigation into the important role of technology in a value-driven business process design for an emerging market.

\section{Extracts and Analysis}

\section{Research Question \#1}

\section{What are the Major Market Opportunities and Constraints the Emerging Markets offer Business Organization Desiring to enter Emerging Markets?}

The primary focus of this question is to elicit relevant information regarding inherent features of emerging markets as well as ascertain specific market opportunities open to the selected agribusinesses within Ghana as an emerging market. Resolution of the question also necessitates uncovering several mitigating factors (if any) the selected cases are confronting in horning their competitive edge within Ghana.

In their response to the question on what constitutes an emerging market, the majority, they viewed it from the perspective of size, policies, and regulatory measures peculiar to an emerging market that makes it vastly different from other types of market. The excerpt below is representative of the responses of participants.

Emerging market is not limited to only one geographical location or region of the world, and it could be found in any part of the world and usually characterized by lower-thanaverage per capita income as well as distinctive rapid rate of economic growth. Another word for emerging market, from my perspective, is any developing economy which include China, India, and Ghana.

unlike developed economy, emerging economy offers reduced tax rates, cheap labour, and accessibility to raw material, for example, all our raw materials can be found in Ghana, no need for importation. This helps in minimizing cost of production which in turn, reduced prices of products and increase patronage and profit.

A closer study of the excerpt above revealed that an emerging market is usually a developing economy with low GDP per capita and highlevel potential for growth. The low GDP per capita underscores the reason why such an economy is undergoing rapid growth in comparison to the developed economy, which is less attractive to the investor. Intense interest at improving their economy, the government of emerging markets formulate several policies directed towards attracting investors and multinational organizations in dire need of expanding the frontiers of their business activities.

Another noteworthy feature of an emerging market, as identified in the excerpt, is the dependence on agricultural products, which coincides with the drive for agribusiness in 
emerging markets. Most of the emerging markets are ripe for investment in agriculturerelated business activities. Hence, raw material is readily available locally with positive implications for increased profit due to low production costs alongside reduced tax.

Responses of participants is consistent with the findings of several studies by [40, 41]. These studies show that emerging market has peculiar characteristics that differentiate it from traditional market. As underscored by participants, emerging economies are vastly different from the developed economy with the traditional market such as the United States, Germany, Japan, and Mexico. For example, according to a report by [40], while emerging markets such as China, India, and Brazil's GDP are US\$8.83 per capita, the United States had US\$59.53. Likewise, World Bank (2019) indicated that Ghana had a growth rate of $6.7 \%$ in 2019 compared to the United States, Japan, and Germany's growth rate of $3 \%$.

In effect, the findings of the study revealed that emerging market is a market with low GDP per capita, reduced tax rate, accessibility to raw materials and cheap labour, and rapid growth rate. Notwithstanding, emerging markets are noted for certain constraints, which often discourages investments or diversification within the agribusiness sector.

Excerpts of Responses of participants below.

Emerging markets are often affected by political instability and other natural disasters which could be very fatal to our business.

The shifting sand of policies has made our work in buying and selling $100 \%$ cotton very difficult, culminating in meager profit. The government need to formulate and enforce relevant policies to remove illegal companies and encourage those with legal right to operate.

We have embarked on intensive training of our staff because most of them lacks adequate knowledge of the production process and how to generate enough patronage through adequate knowledge of market situation.

Themes generated from framework \#1 include.

1. An emerging market is not defined by geographical features but is characterized by lower-than-average per capita income. It includes China, India, and Ghana.

2. Opportunities of emerging markets exist reduced tax, cheap labour, raw material availability.

3. Opportunities of emerging market exist; minimised cost of production, lower product and service prices and increase patronage and profit.

4. Emerging market is affected by macro environmental constrains.

5. An emerging market is affected by macro environmental constrains.

6. Government must act.

7. Internal strength or capacity must be built to overcome constrains.

8. There is a lack of infrastructure framework.

9. Training enhances awareness and faster technology diffusion rate.

10. Developing economies have a mixture of labour costs.

Table 1. Reviewing, Defining and Naming of Themes

\begin{tabular}{|l|l|l|l|}
\hline Market Opportunities & Frequency & Market constrains & Frequency \\
\hline Reduced tax & 2 & Unstable policies & 5 \\
\hline Cheap labor & 2 & Political volatility & 2 \\
\hline Raw material availability & 4 & Poor ICT infrastructure & 5 \\
\hline Low production cost & 5 & Cost of training & 2 \\
\hline Diversification & 3 & Weak institution & 5 \\
\hline Rapid growth & 3 & & \\
\hline
\end{tabular}




\section{Discussions}

In-depth examination of the responses of participants reveals that though a majority (19) of the participants agreed that emerging market has several potential and benefits, yet they indicated that there are certain constraints mitigating increased investment in agribusiness in Ghana, as demonstrated in the excerpt. Reference was made to political instability or institutional voids with concomitant shifting sand of policies which has truncated growth in the agribusiness sector. This tally with [41] study that Ghana is "an enduring neopatrimonialism of a particular Ghanaian sort in which horizontal interest groups are subordinated to vertical patronage relationships" (p.1). This demonstrated that partisanship in Ghanaian politics has created weak institutions where office holders relegate the need of the citizenry to the background in order to observe the party's interest.

That is, the ability of public officials to formulate and carry out policies in accordance with the public interest is heavily constrained by the requirement to service patronage networks [41].

Several policies and ordinances that could have attracted local and international investors with a boost on foreign direct investment were not properly enforced or, in some instances, replaced upon transition from one government to the other. It clearly demonstrates the deplorable level of instability and volatility in the country. It lends credence to [42, 43] findings that inappropriate and unenforced laws and policies, alongside the poor level of skills in ICT limit the urge for investment in the agribusiness sector of Ghana. The low turnover or bankruptcy of several investors affected by illegal companies within the sector was used by [42] to concretize their point.

The result of the study is consistent with studies by [39] that emerging markets are noted for political instability arising from corruption and lack of transparency coupled with administrative delays during the process of registering business operation as well as enforcement of promulgated laws and policies.

Some members of one of the focus groups No. 1 comprising both management and nonmanagement staffs with 8 years working experience (on the average) posited that "Ghana's ICT infrastructure to boost modified technology that could have improve several aspects of agribusiness is lacking". For example, there are appropriate technology that could foster modification of seed or enhance growth rate for high yield. Another focus group member stated: "though we have state-of-theart technology in our establishment, but it has been an onerous task to use them because majority of our suppliers, customers and partners are not familiar with this modern technology, nor know how to use them".

A closer study of the excerpts and themes above, from my perspective, reveals that constraints limiting the establishment of an agribusiness organization in Ghana is both internal and external in nature. Some investors are constrained due to the low level of ICT infrastructure in Ghana, while others are constrained because their partners or customers are unfamiliar with appropriate technology, they have adopted to boost their competitive edge. From the focus group discussion, I discovered that upon integrating appropriate technology, all staffs and non-staffs must be trained on how to use the technology, whether it is a software or machine. To create awareness through adequate training programs, the organization would have to spend a huge sum of money with a concomitant reduction in their profit and turnover.

This finding is in harmony with Epting and Adner, and Kapoor that for the creation of value chain and competitive edge, an agribusiness company should build an enabling ecosystem wherein partners, customers, and lawmakers are willing to adopt the new technology and use it. This means the new technology should not contravene any ordinance in the country, and 
partners alongside customers are willing to use the technology or be trained on its usage. This is very important because the establishment cannot survive without an effective and wellfunctioning ecosystem that embraces its new technology and is ready to patronize its products.

Depicted in Figure 1 is the summary of the numerous opportunities and constraints associated with the creation of value in agribusiness in Ghana. This was drawn based on participants' responses.

A closer study of the chart in Figure 1 and 2 reveals that there are numerous opportunities and constraints associated with investing in agribusiness within the context of Ghana as an emerging market.

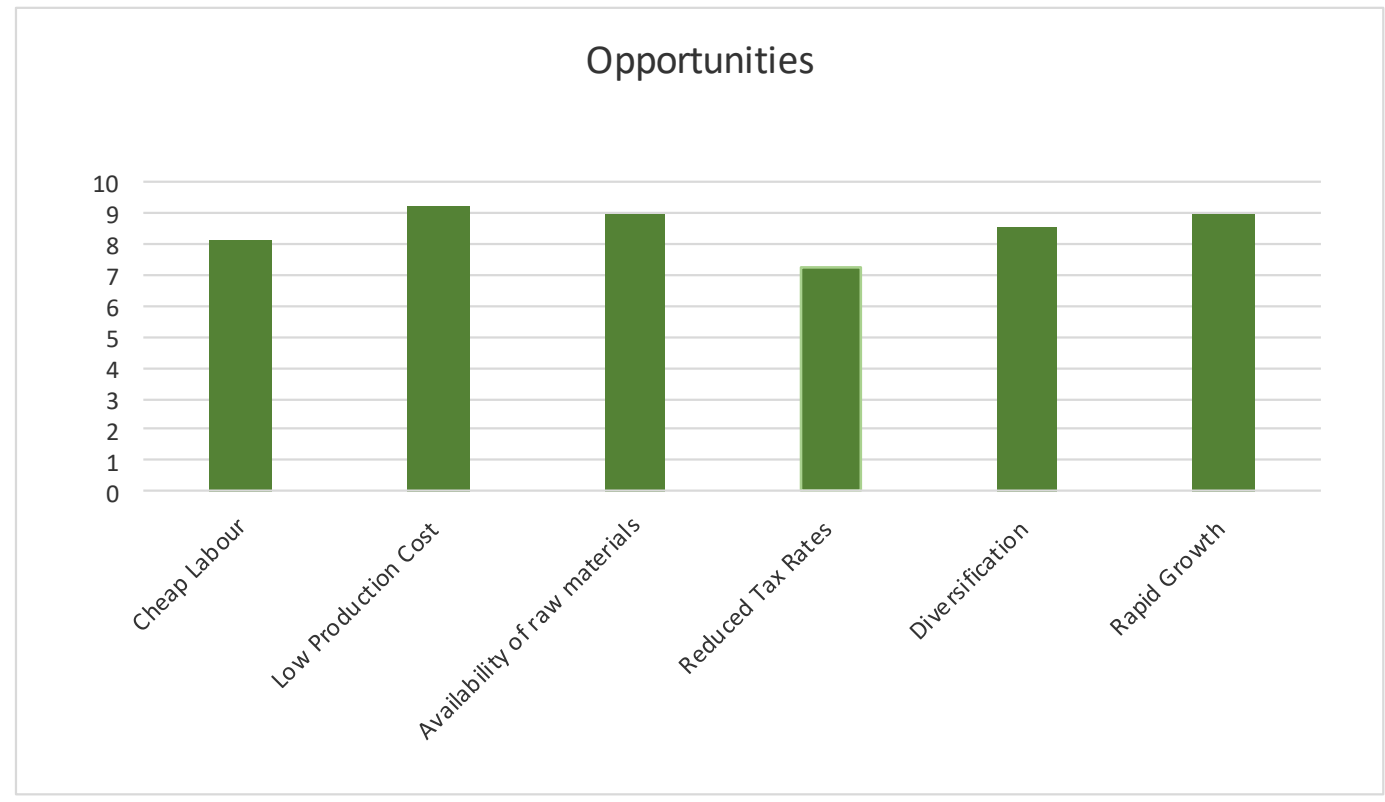

Figure 3. Potential Opportunities

Source: Researcher's Construct (2020)

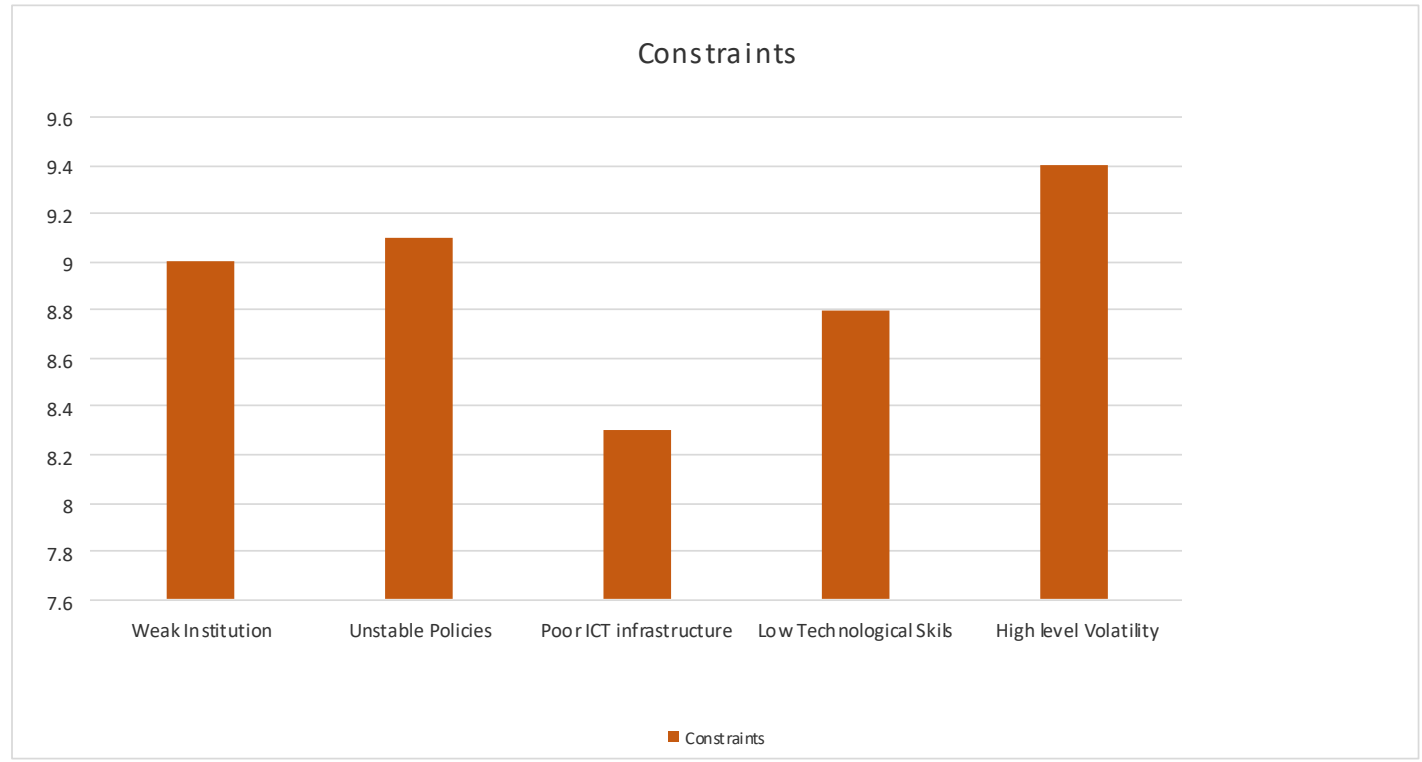

Figure 4. Potential Constraints

Source: Researcher's Construct (2020) 
However, the chart shows that in comparison to other forms of potential opportunities, cheap labour and reduced tax rates received a lower rating. One of the management staffs with 13 years of working experience intimated that "tax rates in Ghana is not necessarily low when compared to other developing countries like Nigeria or Togo, although lower in comparison to developed countries. He indicated that though the amount earmarked by the government could be low, but corruption by public office holders requesting for bribes makes the total cost paid for services higher with negative effect on profit.

Likewise, one member of the focus group No. 2 with 11 years of working experience, indicated that "cheap labour in Ghana is not clear-cut rather it is context-specific, certain locations in Ghana are prone to higher labour cost while others could be lower". This account for the reason why fewer participants agreed that there are cheap labour and reduced tax rates in Ghana.

\section{Conclusion and Implications}

Themes generated from the in-depth interview and focused group also suggested the cost of training or lack of technological skills and political volatility as some of the constraints. The deduced market potentials include, as seen from the table below, coded as blue.

Table 2. Opportunities and Constraints

\begin{tabular}{|l|l|l|l|}
\hline Market Opportunities & Frequency & Market constrains & Frequency \\
\hline Reduced tax & 2 & Unstable policies & 5 \\
\hline Cheap labour & 5 & Political volatility & 2 \\
\hline Raw material availability & 4 & Poor Tech infrastructure & 5 \\
\hline Low production cost & 2 & Cost of training & 2 \\
\hline Diversification & 3 & Weak institution & 5 \\
\hline Rapid growth & 3 & & \\
\hline
\end{tabular}

The findings of the study are consistent with the result of a study by $[2,19,21]$ that agribusiness organization should not only be concerned with internal constraints within the organization. They should also be concerned with external challenges arising from interdependent partners.

In a nutshell, the findings of the study revealed that there are several opportunities for investment in agribusiness in Ghana. It ranges from cheap labor, low production cost, availability of raw materials, reduced tax rates, capacity for diversification, and rapid rate of business growth. However, there are certain inhibitions or constraints limiting the urge for investment in the agribusiness sector in Ghana. These range from weak institutions, unstable and unenforced policies, poor ICT infrastructures, low technological skills, and high-level volatility.
I concur with the submissions of the participants. Ghana has put in place tax incentives to attract investors. One such incentive is the opportunity given to any agribusiness investor or firm to benefit from corporate tax holidays. These firms are free to register under the Ghana Free Zone Authority to enjoy exemption from income tax for about 10 years. Any company under the Free Zone is also entitled to $0 \%$ import duty on any machinery or technological equipment imported. Notwithstanding, as the participants indicated, in reality, due to corrupt practices by public office holders, investors are compelled to pay bribes before accessing tax concessions that they are entitled to, such as import duties. Notwithstanding, in comparison to agribusiness investment in developed countries, the government of Ghana made ample provision for reduced tax rates to attract investors. 


\section{Limitations of Studies}

Limited time to deepen the impacts each of the identified constraints will have on a new entrant's business processes to launch a valuedriven product into an emerging market, degrees of impact of each constrain could be measured and rated so appropriate resources will be spent on overcoming each element.

This was limited to the Agribusiness industry and hence cannot be generalized to other industries within the emerging market of Ghana.

Also, other empirical studies could be conducted utilising the quantitative approach to the research as this was biased towards qualitative approaches.

A lot of intended participants declined even after the promise of hiding their identity due to

\section{References}

[1] Mari S. (April 2015) Communications of the ACM, Vol. 58 No. 4, Pages 27-29 10.1145/2736289 Competing in Emerging Markets, April 2015, Communications of the ACM.

[2] Amankwa-Amoah, J., Debrah, Y. A., Yu, W., Adomako, S., \& Danso, A. (2020). Technology strategies in emerging economies: emerging issues, challenges, and new research. Elsevier B. V: Technological Forecasting and Social Change, 2 (1), p. 1.

[3] Cumming, Douglas \& Zhang, Yelin, 2016. "Alternative investments in emerging markets: A review and new trends," Emerging Markets Review, Elsevier, vol. 29(C), pages 1-23.

[4]Flint, G. D. (2000) What is the meaning of competitive advantage? Advances in Competitiveness Research, 8(1), 121-129. https://www.irbnet.de/daten/iconda/CIB4393.pdf.

[5] Klein, J., 2001. A Critique of Competitive Advantage. Manchester, Critical Management Studies Conference.

[6] Melissa A. Schilling (2015) Technology Shocks, Technological Collaboration, and Innovation Outcomes. Organization Science Published online in fear of their candid response going public and going against company policies.

\section{Acknowledgements}

Some Persons contributed substantially to work in this manuscript (e.g., technically, writing and reading and editing assistance, general), however, the help do not make the mark for authorship hence there were no acknowledgements as co-authors.

\section{Conflict of Interest}

Moreover, no financial and relationship conflicts of interest exist. The article is therefore balanced, objective, and evidence based as possible.

Articles in Advance 1st Apr 2015. http://dx.doi.org/10.1287/orsc.2015.0970.

[7] Sołoducho-Pelc L., Radomska J. (2012), The role of human capital in creating competitive advantage based on technology, ed... J. Kowal, N. Roztocki, Proceedings of the International Conference on ICT Management for Global Competitiveness and Economic Growth in Emerging Economies, pp. 161182.

[8] Sołoducho-Pelc L. (2013), Factors Determining the Process of Creating and Implementing a Strategy Based on Innovation and Technology, Vision 2020: Innovation, Development Sustainability, and Economic Growth, 21st IBIMA Conference 27-28 June, Vienna, Austria, pp. 442-454.

[9] Porter M. E. (1996). What is strategy? Harvard Business Review, November-December, pp. 61-78. [10] Wang C.L., Pervaiz K. Ahmed (2007), Dynamic capabilities: A review and research agenda, International Journal of Management Reviews, Vol. 9, Issue 1, March, pp. 31-51.

[11] Chakravarthy, B.S. (1986) Measuring Strategic Performance. Strategic Management Journal, 7, 437-458. http://dx.doi.org/10.1002/smj.4250070505. [12] Ensign, P. C. (1998). Interrelationships and horizontal strategy to achieve synergy and 
competitive advantage in the diversified firm. Management Decision, 36, 657-668.

[13] Barney, Jay B. 'Is the Resource-Based 'View' a Useful Perspective for Strategic Management Research? Yes." The Academy of Management Review, vol. 26, no. 1, 2001, pp. 41-56. JSTOR, www.jstor.org/stable/259393 Accessed 13 July 2021.

[14]Peteraf, Margaret A. "The Cornerstones of Competitive Advantage: A Resource-Based View.' Strategic Management Journal, vol. 14, no. 3, 1993, pp. 179-191. JSTOR, www.jstor.org/stable/2486921 Accessed 13 July 2021.

[15]Hart, Stuart L. "A Natural-Resource-Based View of the Firm." The Academy of Management Review, vol. 20, no. 4, 1995, pp. 986-1014. JSTOR, www.jstor.org/stable/258963 Accessed 13 July 2021.

[16] Ankli, Robert E. “Michael Porter's Competitive Advantage and Business History." Business and Economic History, vol. 21, 1992, pp. 228-236. JSTOR， www.jstor.org/stable/23703225 Accessed 13 July 2021.

[17] Barney, J. B. (1991), Firm resources and sustained competitive advantage, Journal of Management, Vol. 17, No.1, pp. 99-120.

[18] Wright, P., 1987. A Refinement of Porter's Strategies. Strategic Management Journal, Vol. 8(No. 1), pp. 93-101 www.jstor.org/stable/258963 Accessed 13 July 2021.

[19] Anderson, James C., et al. "Dyadic Business Relationships within a Business Network Context." Journal of Marketing, vol. 58, no. 4, 1994, pp. 1-15. JSTOR, www.jstor.org/stable/1251912 Accessed 13 July 2021.

[20] Amankwah-Amoah, J. "The evolution of science, technology and innovation policies: A review of the Ghanaian experience." Technological Forecasting and Social Change 110 (2016): 134142.

[21] Amankwah-Amoah, J., 2015. Solar energy in sub-Saharan Africa: The challenges and opportunities of technological leapfrogging. Thunderbird Int. Bus. Rev. 57 (1), 15-31.

[22] Vijay M., Kamini B. Published Sep 14, 2005, by FT Press. https://www.informit.com/store/86- percent-solution-how-to-succeed-in-the-biggestmarket-

9780131489073?w_ptgrevartcl=The+Lands+of + Op portunity_404802.

[23]Li, Shaomin, et al. "Corporate Social Responsibility in Emerging Markets: The Importance of the Governance Environment." MIR: Management International Review, vol. 50, no. 5, 2010, pp. 635-654. JSTOR, www.jstor.org/stable/41426815 Accessed 15 July 2021.

[24]Herrmann, Sabine, and Adalbert Winkler. "Financial Markets and the Current Account: Emerging Europe versus Emerging Asia." Review of World Economics / Weltwirtschaftliches Archiv, vol. 145, no. 3, 2009, pp. 531-550. JSTOR, www.jstor.org/stable/40587827 Accessed 15 July 2021.

[25] Kose, M., \& Prasad, E. (2010). Changes in the World Economic Order: A Roadmap. In Emerging Markets: Resilience and Growth amid Global Turmoil (pp. 1-8). Brookings Institution Press. Retrieved July 15, 2021, from http://www.jstor.org/stable/10.7864/j.ctt6wpd2g.5. [26]Azigbo, U. K., (2019). "Strategies for New Product Development in an Emerging Market" Walden Dissertations and Doctoral Studies. 6752 https://scholarworks.waldenu.edu/dissertations/6752

[27] Kothari (2004). Research methodology: Methods and Techniques. New Delhi: New age international (P) limited, publisher http://www.sciepub.com/reference/233432.

[28] Kumar, R. (2011) Research Methodology: A Step-by-Step Guide for Beginners. 3rd Edition. Sage, New Delhi. https://www.scirp.org/(S(oyulxb452alnt1aej1nfow45 ))/reference/ReferencesPapers.aspx?ReferenceID=1 971596.

[29] Bonache, J. and Festing, M. (2020) 'Research paradigms in international human resource management: An epistemological systematisation of the field', German Journal of Human Resource Management, 34(2), pp. 99-123. Doi: $10.1177 / 2397002220909780$ 
[30] Babones, S. (2016) 'Interpretive Quantitative Methods for the Social Sciences', Sociology, 50(3), pp. 453-469. Doi: 10.1177/0038038515583637.

[31]Creswell, JW. 2014. Research Design: Qualitative, Quantitative, and Mixed Methods Approaches. Thousand Oaks: Sage Publications. https://www.scirp.org/(S(i43dyn45teexjx455qlt3d2q ))/reference/ReferencesPapers.aspx?ReferenceID=1 964849.

[32] Yin, R. K. (2018). Case Study Research Design and Methods (6th Ed.). Thousand Oaks, CA: Sage Publishing.

https://www.scirp.org/reference/ReferencesPapers.as px?ReferenceID=2398913.

[33] Creswell, JW. \& Poth, CN. (2018) Qualitative Inquiry and Research Design Choosing among Five Approaches. 4th Edition, SAGE Publications, Inc., Thousand

Oaks. https://www.scirp.org/(S(lz5mqp453edsnp55rrgjct55 ))/reference/referencespapers.aspx ?referenceid $=215$ 5979.

[34] Yin, R.K. (2016). Qualitative Research from Start to Finish, Second Edition. New York: The Guilford Press. ISBN: 978-1-4625-1797-8. 386 pp. https://doi.org/10.1111/fcsr.12144.

[35]Lohfeld, W. (2008). Review: Sharlene HesseBiber \&amp; Patricia Leavy (2006). The Practice of Qualitative Research. Forum Qualitative Sozialforschung/Forum: Qualitative Social Research, 9(1). https://doi.org/10.17169/fqs-9.1.363. [36] Nyumba, T., Wilson, K., Derrick, C., \& Mukherjee, N., (2018) The use of focus group discussion methodology: Insights from two decades of application in conservation. Methods in Ecology and Evolution, 9(1), pp. 20-32.

[37] Overlien C, Aronsson K and Hyden M (2005)

The focus group interview as an in-depth method?
Young women talking about sexuality. International Journal of Social Research Methodology 8(4): 331344.

https://journals.sagepub.com/doi/pdf/10.1177/00219 09619857098

[38] Nowell, L.S., Norris, J.M., White, D.E. and Moules, N.J. (2017) Thematic Analysis: Striving to Meet the Trustworthiness Criteria. International Journal of Qualitative Methods, 16, 1-13. https://doi.org/10.1177/1609406917733847.

[39]Boso, N., Adeleye, I., Donbesuur, F., \& Gyensare, M. (2019). Do Entrepreneurs Always Benefit from Business Failure Experience? Journal of Business Research, 98, 370-379. https://doi.org/10.1016/j.jbusres.2018.01.063.

[40] World Bank Group (2017). Leapfrogging: the key to Africa's development? From constraints to investment opportunities. Retrieved on March 2, 2020, from

http://documents.worldbank.org/curated/en/1215815 05973379739/pdf/Leapfrogging-the-key-to-Africasdevelopment-from-constraints-to-investmentopportunities.pdf.

[41] Booth et al. (2005), What are the drivers of change in Ghana? CDD/ODI Policy Brief No. 1, November 2005 , https://cdn.odi.org/media/documents/1961.pdf.

[42] Francisco, A.H (Jan 24, 2010). Neopatrimonialism in Contemporary African Politics https://www.e-ir.info/2010/01/24/to-whatextent-can-neopatrimonialism-be-consideredsignificant-in-contemporary-african-politics/, pp. 2. [43] Osseo-Asare, F. (1984) Development Paradigms and Realities: Agricultural Development Strategies in Ghana, 1957-1983, Paper presented in College Station, Rural Sociological Society. 